\title{
Molière, Théâtre complet, Tome I
}

\section{Monica Pavesio}

\section{(2) OpenEdition}

\section{Journals}

\section{Edizione digitale}

URL: http://journals.openedition.org/studifrancesi/10558

DOI: 10.4000/studifrancesi. 10558

ISSN: 2421-5856

\section{Editore}

Rosenberg \& Sellier

\section{Edizione cartacea}

Data di pubblicazione: 1 décembre 2017

Paginazione: $546-547$

ISSN: 0039-2944

\section{Notizia bibliografica digitale}

Monica Pavesio, «Molière, Théâtre complet, Tome |», Studi Francesi [Online], 183 (LXI | III) | 2017, online dal 01 février 2018, consultato il 24 janvier 2021. URL: http://journals.openedition.org/studifrancesi/ 10558 ; DOI: https://doi.org/10.4000/studifrancesi. 10558

Questo documento è stato generato automaticamente il 24 janvier 2021.

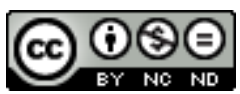

Studi Francesi è distribuita con Licenza Creative Commons Attribuzione - Non commerciale - Non opere derivate 4.0 Internazionale. 


\title{
Molière, Théâtre complet, Tome I
}

\author{
Monica Pavesio
}

\section{NOTIZIA}

MOLIÈRE, Théâtre complet, Tome I, édition de Ch. Mazouer, Paris, Classiques Garnier, 2016, $939 \mathrm{pp}$.

1 Charles Mazouer pubblica il primo tomo dei cinque previsti tra il 2016 e il 2022 della nuova edizione del Théâtre complet di Molière presso le edizioni Garnier.

2 Il volume comprende $\mathrm{i}$ seguenti testi, ordinati in base alla data della prima rappresentazione: le due farse provinciali La Jalousie du Barbouillé e Le Médecin volant, le prime commedie «à l'italienne» L'Etourdi, Le Dépit amoureux, Les Précieuses ridicules, che portarono Molière al successo, Sganarelle ou le cocu imaginaire, commediola burlesca, Dom Garcie de Navarre, commedia seria, L'Ecole des maris e infine Les Fâcheux, prima comédie-ballet. Le opere, accuratamente annotate, sono precedute da una ricca introduzione generale, da una cronologia della vita di Molière fino al 1663 e da brevi prefazioni che ne evidenziano le peculiarità.

3 Dato che il teatro di Molière è composto, in parte, da comédies-ballets, spettacoli ibridi nei quali il testo è accompagnato dalla musica, nella presente edizione, per la prima volta, sono stati aggiunti ai testi, gli spartiti musicali delle pièces curati da musicologhi. Per quanto riguarda gli spartiti di Lully, è stato firmato un contratto con l'editore tedesco delle Euvres complètes del musicista italiano, per poter rendere il più completa possibile questa edizione del teatro di Molière.

4 Il volume è corredato da un'esaustiva bibliografia, da un indice dei nomi, dei personaggi e delle opere. 